Journal of Humanities, Social and Management Sciences (JHSMS)

eISSN: 2788-4791 (online)

https://doi.org/10.47264/idea.jhsms/3.1.1

Vol. 3, No. 1 (January-June 2022), 1-15

https://ideapublishers.org/index.php/jhsms

Research Article

\title{
Way forward for post pandemic online teaching: A case of higher education in Pakistan
}

\author{
Martin Thomas ${ }^{1}$ | Ammar Husnain Khan ${ }^{1}$ | Nazir Ahmad*2 \\ 1. Department of Education, Forman Christian College-University, Lahore, Pakistan. \\ 2. Department of Education, Iqra University, Karachi, Pakistan.
}

*Corresponding Author Email: nahmed094@gmail.com

Received: October 15, $2021 \quad$ Accepted: January 14, $2022 \quad$ Published: January 16, 2022

\begin{abstract}
This small-scale research was conducted to propose a way forward for the post pandemic online teaching in universities of Sindh. Data from 15 university representatives were gathered to identify issues and best practices concerning online teaching and learning in higher education settings of Sindh, Pakistan during the spread of the COVID-19 Pandemic. The data revealed that universities in Sindh face student related, instructor related and online interaction related issues to a significant level while adopting the online teaching modality. The data revealed that universities resolve issues in an ad hoc manner. Therefore, Anderson's online learning model was adapted and proposed for universities to manage online teaching and resolve issues concerning them. The paper also proposes a conceptual framework developed on the theory of reasoned action and the Technology Acceptance Model (TAM) to be adopted for future researcher to further inquire the effect of instructors' perceived usefulness of online teaching and their perceived ease of technology use on instructors' attitudes towards online teaching and their adoption of online teaching.
\end{abstract}

Keywords: online learning, online learning modality, perceived usefulness of education, perceived ease of technology use.

\section{How to Cite:}

Thomas, M., Khan, A. H., \& Ahmad, N. (2022). Way forward for post pandemic online teaching: A case of higher education in Pakistan. Journal of Humanities, Social and Management Sciences (JHSMS), 3(1), 1-15. https://doi.org/10.47264/idea.jhsms/3.1.1

\section{Publisher's Note:}

IDEA PUBLISHERS (IDEA Publications Group) stands neutral regarding jurisdictional claims in the published maps and institutional affiliations.

Copyright: ( 2022 The Author(s), published by IDEA PUBLISHERS (IDEA Publications Group).

Licensing: This is an Open Access article published under the Creative Commons AttributionNonCommercial 4.0 International License (http://creativecommons.org/licenses/by-nc/4.0/) 


\section{Introduction}

In response to the rising concerns about the novel coronavirus disease 2019 (COVID-19) pandemic, universities across the world, including Pakistan were moved from face-to-face to the online teaching modality. However, universities in Pakistan remained at ad hoc and firefighting levels as they targeted only to meet the crisis of the COVID-19 rather than developing a systematic procedure for maintaining quality of education. The Higher Education Commission (HEC), Pakistan therefore identified a rubric to categorize university's quality of online readiness into basic, effective and exemplary tiers and allowed universities to teach online if they could exhibit a reasonable level of readiness (HEC COVID-19 Policy Paper, 2020). Nevertheless, the spread of COVID-19 was so uncertain that none of the attempts by the HEC and the universities in Pakistan could ensure the establishment of a sound mechanism for improving and monitoring the quality of education during the Pandemic.

Serious issues reported regarding the continuity of education at both the public and the private sectors of the province of Punjab included non-availability of conducive learning environment at home, issues concerning affordability and accessibility of internet, challenges in conducting lab classes, conducting online examination and online assignment submission (Punjab Higher Education Commission (PHEC), 2020). Excluding slight variations, many universities which had started online classes during the pandemic are still at the "basic" level of quality. They might have installed a Learning Management System (LMS) but their support mechanism for online resources, lecture recording and disseminating, and online interactions are at superficial level. Faculty have no experience or professional development for teaching online and no system is in place either to assess the quality of teaching and learning or to collect information about connectivity challenges faced by students (HEC COVID-19 Policy Paper, 2020).

The issues indicated by the PHEC are consistent with those identified by different authors. For example, internet connectivity was a major issue but another issue which was reported by students was the access to internet in far off areas where students resided hence had to travel to main cities in order to attend their classes or do their work (Rasheed et al., 2020). Online delivery content is another issue for the students who are at home and not on campus and the reason for that were the digital learning resources (Raes et al., 2020) as they could not access to the resources due to non-availability of internet connection. The technological skills which were required by the teachers were missing as most teachers were not equipped or had practiced the use of technology in classrooms. Such issues with the use and access to equipment, a proper learning environment at home and the skills which were required the most for online teaching modality were missing and such issues and factors do create a divide in the student-teacher connection and to have a conducive learning environment (Cullinan et al., 2021).

However, one of the most important elements to be found missing in online teaching-learning environment foci was the student-teacher connection. There were quite a lot of problems which led to this situation. Learning from internet or online learning is always considered an option and alternative to traditional or conventional teaching methods but COVID-19 pandemic actually made it essential for all schools, colleges and universities to make a shift to run the process and activities (Coman et al., 2020; Aslam et al., 2020). Therefore, the well-established understanding among the educators was that the education provided by any university has no worth if its foci are other than the students' learning (Mushtaq \& Khan, 2012) and if it is neglected it can be seen clearly that learning cannot take place rather it's a mere formality to 
teach online. Previous research studies have identified a variety of factors that affect student learning. These includes (1) school-based factors such as curriculum design, instructional practices, teacher quality and teaching style (ULEAD Education, 2019); and (2) out-of-school factors that involve parenting style (ULEAD Education, 2019) and parents' education (Farooq et al., 2011).

In addition to school-based and out-of-school factors, students' online learning has additional factors which can be categorized under the student related, instructor related, content related and online interaction related factors (Kebritchi et al., 2017; Rehman et al., 2021). These factors may appear as issues for those teachers and students who do not possess the skills of creating or working in a flexible, collaborative and learner-centred online environment (Khan, 2005) or they are non-tech savvy and financially instable to afford the expenses of online learning. Yet another factor which can be associated with online learning is instructor's attitude towards online learning (Teo et al., 2012). Particularly, teachers' positive attitude towards online teaching encourages them to adopt the online modality skilfully while teaching (Liaw et al., 2007). Few teachers did face some issues as they were not equipped with technology or never used it inside a class apart from presenting MS Power Point slides and had to face issues in online teaching and getting to know the basic software usage. This also has something to do with the resources available at hand. As not all universities have the basic technological resources or do not have the funds to operate in a way which provides a way for faculty to use or improve their instruction. Previous studies such as Zamir and Thomas (2019) found that teachers' attitude towards Information and Communication Technology (ICT) determined the practical use of ICT in teaching.

The quality of students' online learning is contingent on the best practices to manage issues concerning these factors. This paper reports issues faced by the universities of Sindh during online teaching and their best practices to manage the issues while teaching online courses offered during the spread on COVID-19. The paper also proposes way forwards in the form of theoretical framework, proposed model for online teaching in a university setting, conceptual framework for future research studies and recommendations. The adapted version of Anderson's (2011) online learning model that can be adopted by the universities in Sindh and universities facing similar problems across Pakistan, to improve the quality of students' online learning and the Technology Acceptance Model (TAM) which is based on the theory of reasoned action is proposed for further studies (see, Ahmed et al., 2021).

\section{Theoretical framework}

We propose the theory of reasoned action to be adopted by the future researchers for such studies. This theory informs that human social behaviour follows reasonably from the beliefs people possess about the behaviour under consideration. These beliefs are usually developed through personal experience, formal education, media or interaction with family or friends and so on. Once people form their beliefs about something they engage in reasoned, but not necessarily rational process (Fishbein \& Ajzen, 2010). This implies that once the teachers will develop an attitude towards the online teaching, their adoption of online teaching will be guided by their attitudes.

The universities in Sindh need to adopt a systematic approach to manage online teaching than have an ad hoc approach. Therefore, we also propose Anderson's (2011) online learning model 
which is a combination of collaborative learning and community of inquiry models as well as the independent learning models. Anderson's online learning model has two major human actors, including instructor and learner who interact with each other as well as with the content during the process of online teaching and learning. Learners can interact directly with the content that they find on the web in multiple forms; however, many choose to seek guidance from an instructor to acquire new learning.

\section{Conceptual framework and the hypotheses}

The proposed research will be guided by the TAM as a conceptual framework (Davis, 1989) which is based on the Theory of Reasoned Action (TRA) (Ajzen \& Fishbein, 1980). The TRA has widely been used to predict people's attitudes towards networking that includes online teaching (Jogezai et al., 2021). Two important constructs for online teaching include perceived usefulness of on online teaching and perceived ease of technology use in online teaching (Davis et al., 1989). These constructs are influenced by instructors' personal variables (PVs) that may include teachers' teaching experience, qualification and exposure to technology to be used during online teaching while environmental variables (EVs) that may include financial support, technological support and technological infrastructure provided by the universities. Instructors' attitude is dependent on these factors which ultimately determine the success of online teaching model adopted by the university (refer to figure 1).

Using the proposed conceptual framework, the following hypotheses have been developed to answer the given research questions:

$\mathrm{RQ}_{1}$ : Is there any association between instructors' personal variables, perceived usefulness of online teaching, perceived ease of technology use, universities' environmental variable concerning online teaching and instructors' attitudes towards online teaching?

$\mathrm{RQ}_{2}$ : Is there association between instructors' perceived usefulness of online teaching, perceived ease of technology use, attitudes towards online teaching and online teaching in university Settings?

The hypotheses for question-1 are developed as follows:

$\mathrm{H}_{1}$ : Perceived usefulness of online teaching among instructors from universities, has a significant effect on their attitudes towards online teaching.

$\mathrm{H}_{2}$ : Perceived usefulness of online teaching among instructors from universities, has a significant effect on their adoption of online teaching.

$\mathrm{H}_{3}$ : Perceived ease of technology use among instructors from universities, has a significant effect on their attitudes towards online teaching.

$\mathrm{H}_{4}$ : Perceived ease of technology use among instructors from universities, has a significant effect on their adoption of online teaching.

$\mathrm{H}_{5}$ : Instructors' personal variables mediate the effect of their perceived usefulness of online teaching on their attitudes towards online teaching in university settings.

$\mathrm{H}_{6}$ : Instructors' personal variables mediate the effect of their perceived ease of technology use on their attitudes towards online teaching in university settings.

$\mathrm{H}_{7}$ : Environment variables concerning online teaching within universities, mediate the effect of instructors' perceived usefulness of online teaching on their attitudes towards online teaching in university settings. 
$\mathrm{H}_{8}$ : Environment variables concerning online teaching within universities, mediate the effect of instructors' perceived ease of technology use on their attitudes towards online teaching in university settings.

The hypotheses for question-2 are developed as follows:

$\mathrm{H}_{9}$ : Instructors' attitudes towards online teaching mediate the effect of their perceived usefulness of online teaching on their adoption of online teaching in university settings.

$\mathrm{H}_{10}$ : Instructors' attitudes towards online teaching mediate the effect of their perceived ease of technology use on their adoption of online teaching in university settings.

Figure 1: Conceptual framework of the proposed research

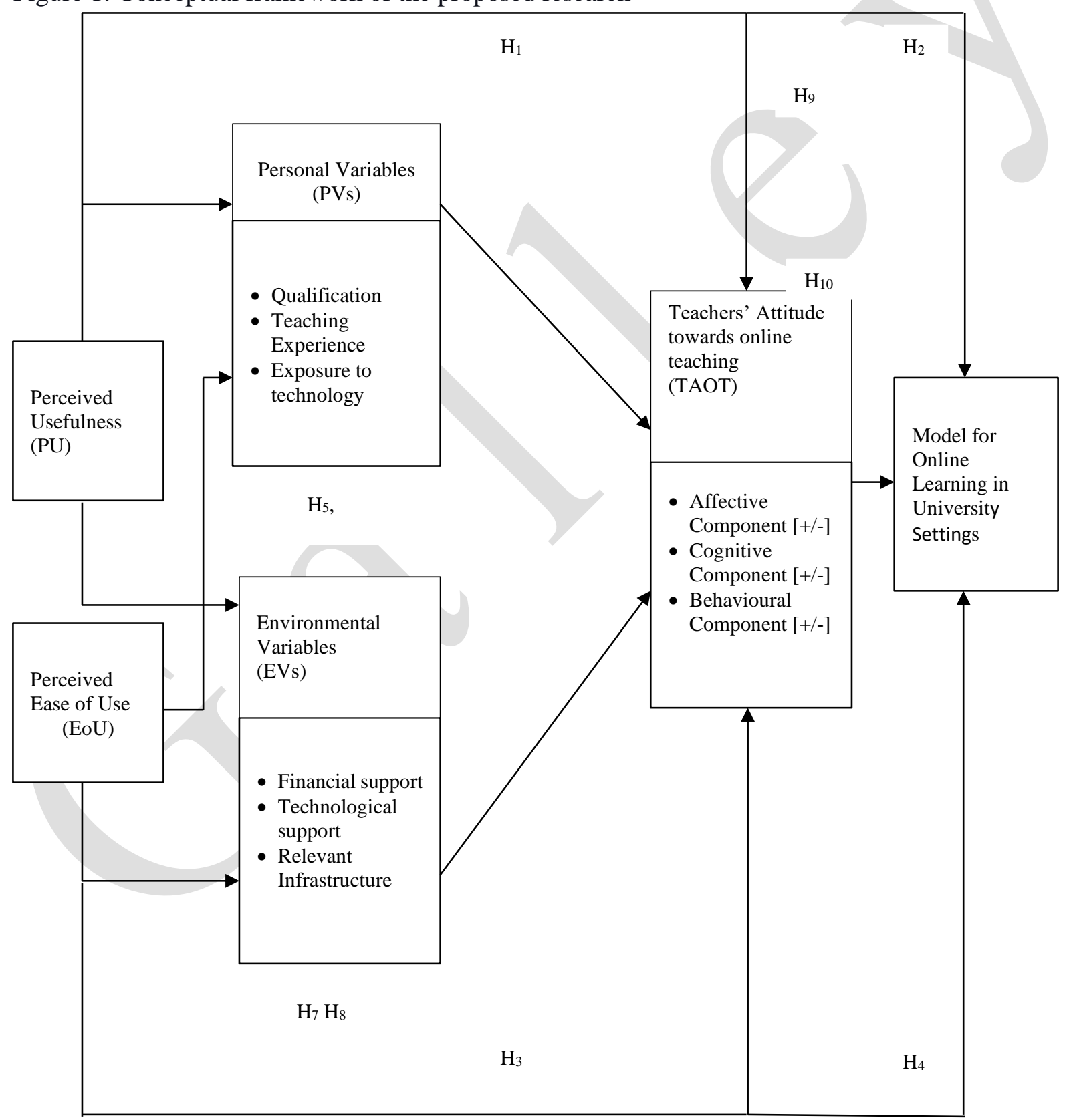

Adapted from: Davis et al. (1989) and Kisanga (2016). 


\section{Research methods}

Using purposive sampling technique (Neuman, 2007), altogether 11 universities were selected from different constituencies of Sindh, namely, Karachi, Jamsoro, Sukker and Benazirabad. These universities have been using online modalities to teach undergraduate to $\mathrm{PhD}$ level courses in the wake of COVID-19. The data gathered from 15 universities representatives indicated that majority of the university instructors $(53.3 \%)$ use Zoom to teach online courses whereas 26.7 percent of them use Google Classroom, 13.3 percent use MS Microsoft Teams and the remaining 7 percent use Google Meet for teaching. The data revealed that 20 percent of the representatives use Blackboard Collaborate, 20 percent Moodle, 20 percent universities' own LMS and the remaining 40 percent either do not use any interface or use WhatsApp or emails to share content material. Out of 15 representative's 33 percent have 5 to 20 students in each class, 40 percent have 21 to 40 students, 7 percent have 41 to 50 students and remaining 20 percent have more than 50 students.

A total of 15 faculty representatives, teaching online teacher education courses during the COVID-19 pandemic, were selected from seven (07) public and four (04) private universities of Sindh, Pakistan. The faculty representatives completed a structured questionnaire to rate the extent to which they were facing student related, content related, instructor related, online interaction related or student online learning related issues. For the analysis purpose six-point rating scale was merged and categorized in three levels, namely low-level issue (point $1+$ point 2), medium level issue (point $3+$ Point 4 ) and high-level issue (point $5+$ point 6 ). The issue was considered significant if the sum of medium level and high-level percentages were more than 50. Using the descriptive analysis technique, responses from the faculty representatives were analysed and reported in this this paper. The structured questionnaire had a descriptive part where the faculty representatives were also asked to describe the best practices that prevail in their universities to manage each issue. As a follow-up, two representatives from private and two from public universities were contacted for gathering supporting data. A list of best practices was prepared from their descriptions and recommendations were provided to further improve the challenging situations.

\section{4. $\quad$ Results}

The analysis of the data revealed that the content related, and the students' online learning related issues were not significant as the sum of high and medium level percentages for them were 39 percent and 40 percent respectively. All the instructors teaching teacher education or English courses were professionally qualified therefore they were able to plan content material and learning activities and assessments tasks reasonably well. However, student related, instructor related, and online interaction related issues were identified as significant and are thus explained in detail as follows.

\subsection{Student related issues and best practices}

The data revealed that 53 percent faculty representatives consider student related issues significant during their online teaching sessions. These involve issues concerning students' expectation, students' readiness and their participation in online learning. Students appear nonserious about assignment deadlines yet become demanding about feedback on their assignment and grades. They become rude while communicating with the instructors or their peer groups. 
They lack skills to use computers and internet and/or consider online learning useless. Students' negative attitude towards online learning limits their participation in the online sessions and accessing and reading course material made available to them and students do not become self-regulated learners (Kebritchi et al., 2017; Saeed et al., 2021).

The selected faculty representatives indicted three best practices. First, communicating with students through WhatsApp or emails on a regular basis and trying to resolve student related issues by discussing with them. Second, discussing matters with the Head of the Department (HoD) or faculty assigned to discuss matters with students. Third, assigning bonus marks for attendance, participation and timely submission of assignments.

\subsection{Instructor related issues and best practices}

The data revealed that 53 percent faculty representatives consider instructor related issues significant during their online teaching sessions. The result suggests that majority of instructors do not adopt the learner-centred approach while teaching and they do not add collaborative activities in the course material. They have limited interaction with students thus do not provide the technical support that students need to participate in online teaching sessions. One reason can be that they are uncomfortable in switching from face-to-face to online classes as they feel that online teaching has less worth when compared with face-to-face teaching and learning (Kebritchi et al., 2017).

This change did help the teachers to get equipped and learn new technology and instructional methods but also felt the lack of interaction. Internet connectivity was a major problem for many as if the connection is slow the cameras will not work, or the sound is not clear. And giving the benefit of doubt to the students, instructors could not do anything most of the time if a student is saying that they do not have a stable connection. If the cameras are turned off, it was felt that the connection is missing between the faculty and students and that is where the instructors saw this as a big issue and preferred that face-to-face teaching modality was more convenient environment and better to work in.

Three best practices to manage instructor related issues were highlighted by the university faculty representatives from Sindh. These included assessing the quality of online instructional material on a regular basis, providing professional development support for instructors to prepare course material and providing technical support for online classes. In some cases, the instructional quality was assessed either through online classroom observations by the university management or by assessing content material placed on the LMS provided by the university. Some universities provide professional development support by arranging in-house informal professional development activities, such discussion with senior faculty members, or arranging frequent webinars. Technical support for online classes was provided by allocating IT personnel to monitor classes and functioning of LMS on a regular basis.

\subsection{Online interaction related issues and best practices}

The analysis of the data revealed that 53 percent faculty representatives consider online interaction related issues significant during their online teaching sessions. This means that majority of instructors in the universities of Sindh do not use student-led teams to complete classroom tasks, they provide insufficient opportunities for students to access and read 
computer assisted material. The content, which was to be taught were also recorded sometimes, tasks given, or the reading material was sent out to the students either through email or LMS and students were expected to work on their own which would not work for every course as every course and content requires different ideas of instruction to work with.

There it was felt the lack of interaction and interest from the student's side, and this led to problems in understanding as well. They exhibit insufficient abilities to develop studentteacher interaction through synchronous or asynchronous modes and exhibit insufficient evidence of co-planning with other colleagues. The university representatives identified that they have 5 to 20 percent students who face connectivity or internet affordability issues during their online classes and are at the risk of being left behind those with digital accessibility. However, the universities do not have a systematic mechanism to either acquire data about such students or follow them to provide proper support.

The universities in Sindh use various online tools and applications (Apps) to develop online interaction among students, instructors and university management. These tools or Apps include, WhatsApp, emails, LMS and telegram. Some universities have developed digital ethics policies so that students avoid misusing the available communication forums. Some universities give leverage to the faculty members to interact with students or teachers using a mode of communication of their own choice whereas other universities conduct workshops or provide video recordings for instructors to understand best practices concerning online interaction or planning and teaching. Course contents in some universities are developed by the instructors themselves which are normally available for students on the LMS a week before the session. The quality of the courses content is assessed by the management and their observations are highlighted in faculty meetings. Some universities provide access to different relevant resources which can be used for course development

\subsection{Way forward}

The current research found that a number of factors affected the process of online teaching within the universities of Sindh during the COVID-19 pandemic situation. These factors can be categorized into personal variables and environmental variables. Personal variables included instructors' qualification, teaching experience and their exposure to technology. Environmental variables on the other hand included, funding or financial and technological support for instructors or students to use online modality for teaching or learning and the provision of relevant infrastructure such as Leaning Management System (LMS), computers, audio and visual devices and so on from the universities.

Both the personal and environmental factors affect instructors' subjective perception where they believe that technology is useful for students' learning, which can be termed as perceived usefulness, or it is easy to use, which can be termed as ease of technology use. These factors consequently affect instructors' attitudes towards online teaching. Previous studies such as Teo et al. (2012) found that teachers' attitude towards online teaching, perceived usefulness and their ease of technology use, effect on their intention (and actual use) to use of technology. We thus propose that the future researchers need to explore the following research questions concerning online teaching in universities in Sindh or higher education institute is Pakistan facing challenges similar to that of universities in Sindh. 


\section{Online teaching in university settings}

\subsection{Nature of learning}

Instructors of universities in Sindh need to adopt a learner-centred approach while teaching through online modality. However, using the online teaching modality requires decision making in selecting the nature of student learning outcomes and relevant learning activities to achieve the expected learning outcomes. Anderson (2011) has cited Prensky to identify the nature of learning outcomes and suitable activities to achieve these outcomes. These outcomes and learning activities are presented in the Table-1.

Table-1: Nature of learning outcomes and activities to achieve learning outcomes

\begin{tabular}{|c|c|}
\hline $\begin{array}{l}\text { Nature of Learning } \\
\text { Outcomes }\end{array}$ & Learning Activities \\
\hline $\begin{array}{l}\text { Expected Students' } \\
\text { Behaviour }\end{array}$ & $\begin{array}{l}\text { - Model the required behaviour so students can imitate the behaviour } \\
\text { - Provide feedback on students' behaviour } \\
\text { - Ensure that students practice the required behaviour }\end{array}$ \\
\hline & $\begin{array}{l}\text { - Play games and allow students to device new rules and procedures } \\
\text { - Play games which require novel outcomes }\end{array}$ \\
\hline Learning Facts & $\begin{array}{l}\text { - Ask students to associate various concepts and idea with each other } \\
\text { - Have drill work for students to allow them to practice concepts or } \\
\text { mathematical functions for a number of times } \\
\text { - } \text { Ask students to answer questions on various aspects of relevant topics }\end{array}$ \\
\hline Making judgment & $\begin{array}{l}\text { - Ask students to review cases and answer different questions about them } \\
\text { - Allow students to make choices while working on various tasks. For } \\
\text { example, which colour, font and text will be suitable for a flyer, provide } \\
\text { justification for your choices } \\
\text { - Use peer tutoring and coaching technique to acquire procedural } \\
\text { knowledge. }\end{array}$ \\
\hline $\begin{array}{l}\text { Acquiring language } \\
\text { ability }\end{array}$ & $\begin{array}{l}\text { - Ask students to speak sentences or pronounce various words as native } \\
\text { speakers speak } \\
\text { - Ask students to practice interacting with people in different situations }\end{array}$ \\
\hline $\begin{array}{l}\text { Learning } \\
\text { Observation }\end{array}$ & $\begin{array}{l}\text { Show videos to students and let students see how expert observe a } \\
\text { phenomenon }\end{array}$ \\
\hline Reasoning & Let students complete various puzzles and solve problem situations \\
\hline Learning Skills & $\begin{array}{l}\text { Let students practice various skills and while they practice gradually increase } \\
\text { difficulty level of the tasks }\end{array}$ \\
\hline nance roles & Let students memorize dialogues and allow them to play different roles \\
\hline Learning Theories & $\begin{array}{l}\text { - Let students find out logic in various aspects of theories } \\
\text { - } \quad \text { Provide step by step guidance for students to understand theories } \\
\text { - Let students ask questions about various aspects of theories and } \\
\text { encourage them to find answers to those questions through library, } \\
\text { online research or through interview relevant people. }\end{array}$ \\
\hline
\end{tabular}

\subsection{Interactions of human actors with each other and with the content}

Anderson (2011) presents a collaborative, and community-of-inquiry model which identifies a process of interaction between student and instructor and their interaction with the course 
content. Figure 2 illustrates an adapted version of the model by Anderson (2011) considered to be suitable for the universities in Sindh. The model identifies a number of online interactions which can be effectively managed to improve the quality of online teaching.

\subsubsection{University-instructor, staff, students, and university-content interactions}

Universities should identify their requirements in the form of policies, procedures and standard operating procedures and the instructors, students and administrative staff follow them. Universities are required to provide a systematic support throughout the process by establishing LMS, assigning online learning support teams, providing professional development opportunities, monitoring quality of the content, online interaction and assessments.

\subsubsection{Student-content, teacher-content and content-content interactions}

A student studying an online course can directly access online resources and interact with the relevant content material available online in the form of e-books, research articles, YouTube videos, blogs and other resources. Additionally, students can also get access to the content material archived on the LMS, during their participation in the community-of-inquiry or collaborative learning activities. Similarly, the instructor teaching the online course can access online resources to structure handouts and learning activities for students and place them on the blackboard, Moodle, university's own LMS or any other suitable interface. The university or the instructor teaching the course can identify relevant online resources and link them with the LMS for students to have an intensive reading around the concepts discussed during the synchronous or asynchronous sessions.

\subsubsection{Student-teacher and student-student interactions}

Student-teacher interaction can take place within a community-of-inquiry in synchronous or asynchronous modes, which is developed by the instructors and students' sharing of knowledge, skills and attitudes (Picciano, 2017). The instructor can have interactive sessions by using Zoom, Google Classroom, Google Meet, Microsoft Teams, Blackboard Collaborate or any other available communication software. Student-student interaction is quite an important ingredient of the learner-centred approach. Therefore, the collaborative learning activities can be designed in student-led teams where they can facilitate each other's learning and have a control over their pace and course of action. In addition to this, they can interact with the instructor on one-to-one basis to share their progress and concerns or to seek guidance about the course content.

\subsubsection{Teacher-teacher interaction}

Universities in Sindh are suggested to use the 70:20:10 professional development model presented by McCall, Lombardo and Morrison and design a special professional development program for instructors (Joshi, 2018). The Communities of Practice (CoP) are proposed where technologically advanced old timers and experienced members (expert knowers) of the university faculty adopt a facilitator's role and those lacking computer and internet skills participate as newcomers (Mohajan, 2017). Around 70 percent of the total instructors' professional development time may be spent for on-the-job support, 20 percent on the feedback from old-timers and expert knower and 10 percent on formal professional development 
sessions to introduce various online teaching, interactive learning and assessment tools and effective use of LMS (Joshi, 2018) (refer to figure 2).

Figure 2: Model for online learning at university setting

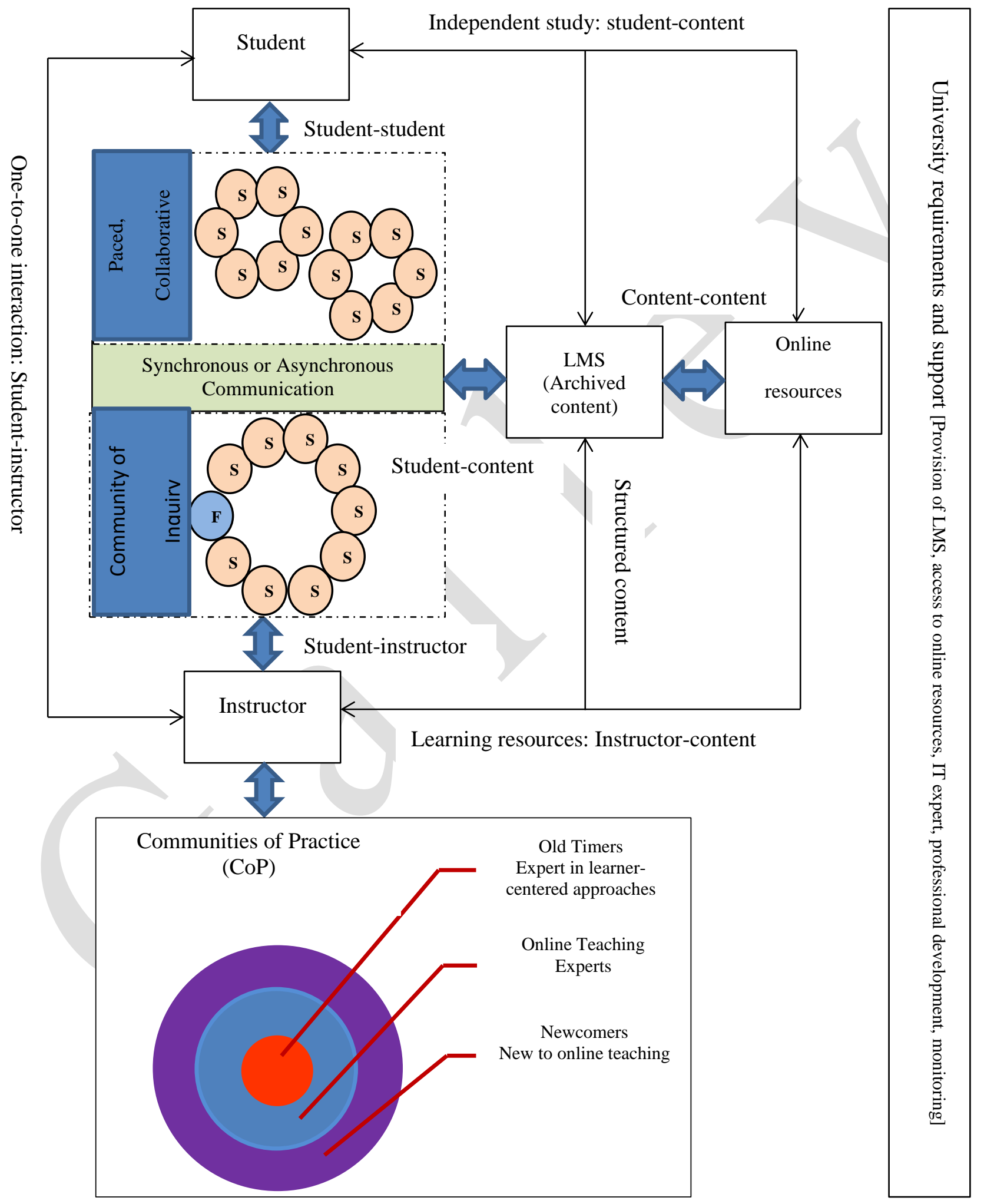

Adapted from: Anderson (2011). 


\subsection{Teachers' attitudes}

Teachers' attitudes towards online teaching are psychological tendencies that they express by evaluating the overall online teaching modality. This may be seen as liking versus disliking, approving versus disapproving or favouring versus disfavouring the concept of online teaching, its structure and its implementation. Teachers' attitudes towards online teaching can have three components (a) affective component, which may include teachers' feelings or emotions associated with online teaching; (b) cognitive component, which may involve thoughts, beliefs and attributes associated with online teaching; and (c) behavioural component, which may involve past behaviours with respect to online teaching. Teachers' attitudes may differ in valence, which is related to strength, or direction which represents positive or negative attitude (Maio \& Haddock, 2012).

\section{Conclusion and recommendations}

This small-scale research identified three significant issues, namely student related issues, instructor related issues and online interaction related issues that universities in Sindh encountered while managing online teaching during COVID-19. It was suggested that universities use the proposed model to manage online teaching in a systematic manner than adopting an ad hoc approach. The paper also proposes a conceptual framework developed on the theory of reasoned action and the TAM to be adopted for future researcher to further inquire the effect of instructors' perceived usefulness of online teaching, their perceived ease of technology use on instructors' attitudes towards online teaching and their adoption of online teaching.

- After considering challenges faced and practices adopted by the universities, the following recommendations are made to further improve the situations.

- To avoid confusions concerning expectations from online teaching, instructors are suggested to understand students' as well as their own and the university's expectations from the course.

- The relevant rules and policies for online teaching should meet the expectations of all the stakeholders and these rule and policies are communicated in the beginning of the course. This will enable students to understand both rewards of meeting the expectations and consequences of failing to meet the expectations. Apart from this, having clear understanding of the expectations will encourage students to become selfmotivated and self-directed leaners towards acquiring domain specific knowledge and skills as well as computer and internet skills. This will consequently increase students' computer and internet self-efficacy (Kebritchi et al., 2017).

- The universities should provide professional development opportunities for students so that they can understand the difference between face-to-face and online teaching and adopt a personalized learning style by setting their goals, practicing positive communication and engaging in metacognition activities so that they can reflect on their learning, challenges in learning and way forward.

- The universities should develop continuing Professional Learning and Development (CPLD) programs for instructors taking online classes. The scope of these programs must be preparing instructors at establishing learner-centred environment during online teaching and preparing them better to teach in remote settings. With such skills, 
instructors will develop a positive attitude towards online teaching and consider both face-to-face and online learning having the same worth.

- The instructors should be provided with CPLD that support them remold their personalities for teaching such as empathetic teaching, catering to social-emotional needs of students in universities, positive communication and community building during online education. This will enable them to address issues pertinent to social bonding with students.

- The universities in Sindh should adopt the proposed model in Figure 2 to effectively manage to improve the quality of online teaching. This model will enable the universities to adopt a systematic approach to manage issues concerning online teaching.

- Under the public private partnership banner a consortium should be developed and educational technology (EdTech) solution providers and experts from public and private universities and universities create teaching and learning content for university instructors and students. This will enable instructors to provide similar learning opportunities for students from all settings.

- The data revealed that 40 percent university representative do not use LMS. Therefore, the university instructors should be trained for using personal learning networks such as Edmodo, so that they can utilize it at their personal capacity to upload learning and assessment material for the students to use in the synchronous and asynchronous modalities.

- The research provided a starting pointing for future research studies therefore future research should be conducted by adopting the proposed conceptual framework so that university administration and policy level propositions can be made.

\section{References}

Ahmed, S. N., Rehman, S. U., \& Said Muhammad Khan. (2021). Online graded assessment of Saudi EFL learners during the Covid-19 pandemic: A successful implication of TAM. Liberal Arts and Social Sciences International Journal (LASSIJ), 5(1), 667685. https://doi.org/10.47264/idea.lassij/5.1.43

Ajzen, I., \& Fishbein, M. (1980). Understanding attitudes and predicting social behaviour. Prentice-Hall.

Anderson, T. (2011). The theory and practice of online learning (2nd Edition). AU Press.

Aslam, T., Rizvi, S. M. A. S., \& Ahmad, J. (2020). Virtual learning strategies during Covid19: A case study of the university of Lahore, Pakistan. Liberal Arts and Social Sciences International Journal (LASSIJ), 4(2), 427-441. https://doi.org/10.47264/idea.lassij/4.2.33

Coman, C., ȚîRu, L. G., Meseșan-Schmitz, L., Stanciu, C., \& Bularca, M. C. (2020). Online teaching and learning in higher education during the Coronavirus pandemic: Students' Perspective. Sustainability, 12(24), 10367. https://doi.org/10.3390/su122410367

Cullinan, J., Flannery, D., Harold, J., Lyons, S. \& Palcic, D. (2021). The disconnected: Covid19 and disparities in access to quality broadband for higher education students. International Journal of Educational Technology in Higher Education, 18(26), 1-21. https://doi.org/10.1186/s41239-021-00262-1 
Davis, F. D. (1989). Perceived usefulness, perceived ease of use, and user acceptance of information technology. MIS Quarterly, 13(3), 319-340. https://doi.org/10.2307/249008

Davis, F. D., Bagozzi, R. P., \& Warshaw, P. R. (1989). User acceptance of computer technology: A comparison of two theoretical models. Management Science, 35(8), 928- 1003. https://doi.org/10.1287/mnsc.35.8.982

Farooq, M. S., Chaudhry, A. H., Shafiq, M., \& Berhanu, G. (2011). Factors affecting students' quality of academic performance: A case of secondary school level. Journal of Quality and Technology Management, VII(II), 01-14.

Fishbein, M., \& Ajzen, I. (2010). Predicting and changing behaviour: The reasoned action approach. Psychology Press.

HEC COVID-19 Policy Paper (2020). Policy guidance note 5: Online readiness. HEC, Pakistan.

https://hec.gov.pk/english/HECAnnouncements/Documents/nCoVirus/Covid-19Policy-Guidance-No.5-Online\%20Readiness.pdf

Jogezai, N. A., Baloch, F. A., Jaffar, M., Shah, T., Khilji, G. K., \& Bashir, S. (2021). Teachers' attitudes towards social media (SM) use in online learning amid the COVID-19 pandemic: the effects of SM use by teachers and religious scholars during physical distancing. Heliyon, 7(4), e06781.https://doi.org/10.1016/j.heliyon.2021.e06781

Joshi, M. (2018). Learning: 70:20:10. Bookboon Learning.

Kebritchi, M., Lipschuetz, A., \& Santiague, L. (2017). Issues and challenges for teaching successful online courses in higher education: A literature review. Journal of $\begin{array}{llll}\text { Educational Technology } & \text { Systems, } & \text { 46(1), }\end{array}$ https://journals.sagepub.com/doi/abs/10.1177/0047239516661713

Khan, B. H. (2005). Managing e-learning: Design, delivery, implementation, and evaluation. Information Science Publishing. http://BooksToRead.com/elearning

Kisanga, D. H. (2016). Determinants of teachers' attitudes towards e-learning in Tanzanian higher learning institutes. International Review of Research in Open and Distributed Learning, 17(5), 109-125. https://doi.org/10.19173/irrodl.v17i5.2720

Liaw, S. S., Huang, H. M., \& Chen, G. D. (2007). Surveying instructor and learner attitudes toward e-learning. Computers and Education, 49, 1066-1080. https://doi.org/10.1016/j.compedu.2006.01.001

Maio, G. R. \& Haddock, G. (2012). The psychology of attitudes and attitude change. SAGE Publications.

Mohajan, H. K. (2017). Role of communities of practice for the development of the society. Journal of Economic Development, Environment and People, 6(3), 1-23. https://www.ceeol.com/search/article-detail?id=572401

Mushtaq, I., \& Khan, S. N. (2012). Factors affecting students' academic performance. Global Journal of Management and Business Research, 12(9), 17-22. https://globaljournals.org/GJMBR Volume12/3-Factors-Affecting-StudentsAcademic.pdf

Neuman, W. L. (2007). Basics of social research: Quantitative and qualitative approaches (2 ${ }^{\text {nd }}$ ed.). Pearson

Picciano, A. G. (2017). Theories and frameworks for online education: Seeking an integrated model. Online Learning Journal, 21(3), 166-190.

Punjab Higher Education Commission [PHEC] (2020). Minutes of the $3^{\text {rd }}$ meeting of the PHEC Committee to "discuss the policy guidelines regarding online learning and assessment." PHEC. 
Raes, A., Detienne, L., Windey, I., \& Depaepe, F. (2020). A systematic literature review on synchronous hybrid learning: Gaps identified. Learning Environments Research, 23, 269-290. https://doi.org/10.1007/s10984-019-09303-z

Rasheed, A. R., Kamsin, A., \& Nor, A. A. (2020). Challenges in the online component of blended learning: A systematic review. Computers \& Education, 144, https://doi.org/10.1016/j.compedu.2019.103701

Rehman, N., Zhang, W., \& Iqbal, M. (2021). The use of technology for online classes during the global pandemic: Challenges encountered by the schoolteachers in Pakistan. Liberal Arts and Social Sciences International Journal (LASSIJ), 5(2), 193208. https://doi.org/10.47264/idea.lassij/5.2.13

Saeed, B., Ullah, A., \& Khan, M. A. (2021). Attitude of university students on online teaching under corona virus pandemic situation in Pakistan. Liberal Arts and Social Sciences International Journal (LASSIJ), 5(1), 28-40. https://doi.org/10.47264/idea.lassij/5.1.3

Teo, T., Ursavas, O. F., \& Bahcekapili, E. (2012). An assessment of pre-service teachers' technology acceptance in Turkey: A structural equation modelling approach. The Asian-Pacific Education Researcher, 21(1), 191-202. https://researchrepository.murdoch.edu.au/id/eprint/48415/

ULEAD Education (2019). Factors influencing student learning. Hanover Research, Salt Lake City.

Zamir, S. \& Thomas, M. (2019). Effect of university teachers' perceptions, attitude and motivation on their readiness for the integration of ICT in classroom teaching. Journal of Education and Educational Development, 6(2), 308-326. http://journals.iobmresearch.com/index.php/JEED/index 